\title{
Analysis of Traditional Urban Morphology of Korean Contemporary City and Institutional Measures for Preservation1)
}

Choi, Min-Ah*

* Corresponding author, Land and Housing Institute, Korea Land and Housing Corporation, South Korea (minah_choi@Ih.or.kr)

\section{A B S T R A C T}

In the present circumstance of exploring measures for sustainable development, finding and using planning elements of historical city is getting important as a urban planning tool. Thus this study aims to examine the characters of Korean traditional urban form through three periods, Josun, modern and contemporary eras. Three urban centers representing different characteristics were selected; historical center based on 14th century's traditional planning, modern period urban center, which is related with development of railway, and contemporary urban center of late 20 th century.

Analyse of urban tissue, composed with form and scale of street network, blocks and plots, shows that each urban center of Seoul has certain common attributes in terms of morphology in spite of the difference of formation and development period. However this historical urban forms are rarely applicated in the current urban planning, such as new-town planning or district unit plan. This shows the necessity of modification of urban regulation for preserving the identity of our city and pursuing sustainable development.

(c) 2014 KIEAE Journal
K Y E W O R D S

Urban morphology, Historical city,

Urban tissue analysis,

Comparison of urban centers forms

\section{Introduction}

\subsection{Background and purpose of research}

Since the $21^{\text {st }}$ century, major nations have established sustainable development as the basic guideline for their urban planning and are seeking for various measures. Sometimes, it is demonstrated as a new way of urban development such as transition to energy-friendly city through reduction of greenhouse gas exhaustion or compact urban structure, but other times, planning elements used in traditional cities are resurfaced to be applied in contemporary urban planning, which emphasizes the regional

pISSN 2288-968X, eISSN 2288-9698 http://dx.doi.org/10.12813/kieae.2014.14.2.047

1) This paper is based on partial extracts from "Linéarité des villes nouvelles de Séoul: une nouvelle centralité face à l"extension urbaine et au développement du réseau de transport", doctor's degree dissertation at University Paris 8, and complemented. characteristics and historicity.

The trends of urban planning aims to preserve the uniqueness and identity of the city rather than following standardized and functional urban planning which had been prevalent in late $20^{\text {th }}$ century. This phenomenon indicates that preservation of urban historicity has become an important factor in urban planning field. It also provides the linkage between preservation of urban historicity and ecological environment city by reviewing the ecological and environmental principles applied in cities in the past.

Thus, the purpose of this study is to propose urban planning method in order to identify historicity of Korean cities and the characteristics of its components. The preceding researches regarding urban historicity have the tendency to focus only on areas built during Joseon dynasty and before. However, this study also covers the cities built during Japanese occupation period to expand 
the range of historicity of Korean cities.

The main contents of this study is the urban tissue analysis of city centers developed before $19^{\text {th }}$ century, modern urban centers linked with railroad development during early $20^{\text {th }}$ century and contemporary urban centers built after 1960s. The analysis compares the forms and characteristics of areas developed in different times and identifies the historicity remaining in present cities of Korea. The ultimate purpose of this study is to seek for identity of Korean cities by comparing the components of city forms of each era and to propose how to preserve historicity of Korean cities by analyzing the current urban planning status and systems.

\subsection{Research method and range}

The research method is the city form analysis to identify the historical characteristics of modern cities. Areas representing the characteristics of each era are selected and maps of those areas are used to analyze the forms and scales of urban tissues. Classification used for the form analysis is street network, block, lot and building which are major components of urban form analysis and also have been used by Conzen, Panerai, etc.

The research subject is Seoul which is the most developed city in Korea and has various urban change characteristics gained through Joseon dynasty and Japanese occupation period. The traditional urban center is Jongno and modern urban centers are Yongsan, Cheongnyangni and Yeongdeungpo which have been developed by formation of railway stations and perform the role of sub-central areas. The present urban center is the Gangnam area which has been developed since late 1960 s to compare the forms between the historical areas naturally developed in the past and the contemporary areas formed by urban planning during late $20^{\text {th }}$ century. Computerized land registration map with scale of 1:1000 was used for research analysis.

\section{Theoretical Background and Preceding Researches}

\subsection{Theoretical background}

Urban morphology is an academic field that analyzes the components and characteristics of physical urban forms in order to explain the interrelation between components and urban historicity and the process of urban formation and relationship with non-physical factors such as society and humanity. (Yang, Seungwoo, 2000) The forms of cities are varied by the period of their development thus indicates the chronological characteristics. Also, different urban characteristics are identified within a single city which are differentiated by the period and method of development. (Cho, Junbeom, 2013)

Urban morphology was first originated from German geography since late $19^{\text {th }}$ century and mainly has been developed in Europe where cities were developed continuously. In Italy, urban morphology has been studied since 1940 s by the Muratoris. Saverio Muratori established the framework for urban morphology by studying the relationship between the two-dimensional building site and its external space located in urban tissue. The approach understanding the structure within the urban issue has been developed to three-dimensional urban form analysis after Mareto and Casinia's researches.

In the United Kingdom, urban morphology has been developed mainly by the Conzenean school. It was an evolutionary perspective on urban formation process and M.R.G Conzen identified the urban formation process through analysis of street network, lot and building forms from the perspective on utilizing flat urban area, structure

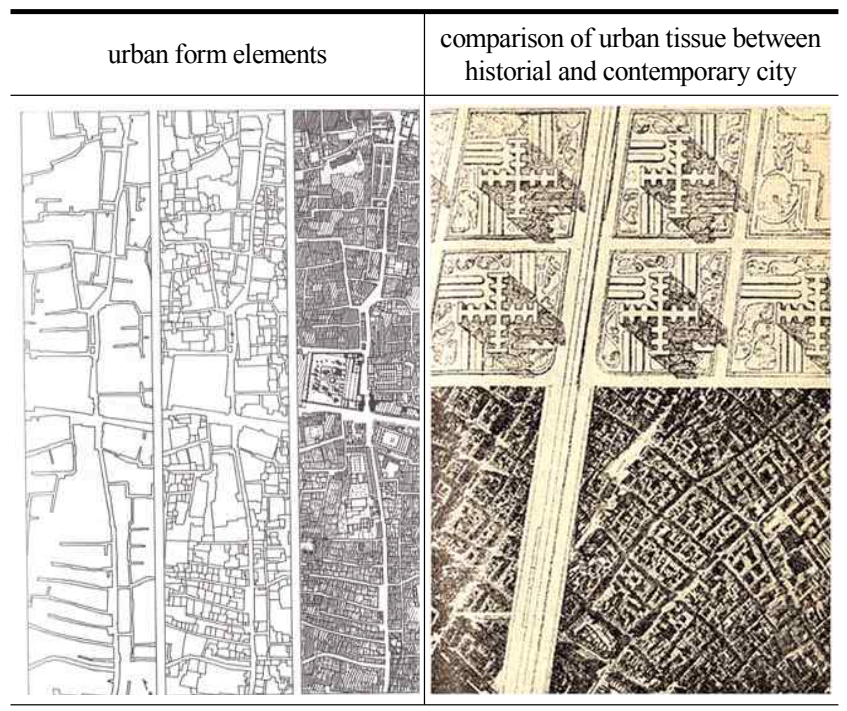

Fig 1. Urban form elements and comparison of urban tissues between historial and contemporary city(source: Ph. Panerai, Analyse urbaine, 1999, Le Corbusier, Urbanisme, 1945) 
and land in historical urban centers and traditional cities. (Sohn, Sekwan, 2000)

These kinds of Conzenean urban morphology methods are also demonstrated in France as well. In France, urban morphology was initiated in the early $20^{\text {th }}$ century from the perspective on recognizing the city as an organic structure. In the late $20^{\text {th }}$ century, Philip Panerai and others identified the arrangement and morphological characteristics of street network, block, lot and structures by analyzing the maps and blueprints from wide range of eras in order to explain the changes, formation logic and process of cities. Urban morphology in France was not only a work process identifying the historical urban characteristics but also a method regarding modern city planning and designing and there are many ongoing analysis and researches on various urban tissues and forms.

Urban tissue analysis reveals the difference in forms and structures between the planned cities and historically developed cities. As demonstrated in Le Corbuisier's
Radian City focusing on vehicles in 1930s, the historical European cities demonstrate dense and closed urban structure while planned cities developed by modern city planning theories demonstrate open and low-density figures.

The urban form analysis identifies the changes process, formation logic and social changes and is an important factor demonstrating the urban historicity. Therefore, it is possible to succeed the historical characteristics of previous cities to modern city planning by applying the historical urban form factors identified through analysis to current city planning.

\subsection{Preceding researches}

The preceding researches are classified into theoretical researches on urban morphology and direct analysis on forms of individual cities. The representative research on urban morphology is Sohn, Sekwan's research which compares the research methods of Conzenean School and

Table 1. Preceding researches on urban morphology

\begin{tabular}{|c|c|c|c|c|c|}
\hline & authors & analysis elements (site) & analysis materials & methods & results \\
\hline \multirow{3}{*}{$\begin{array}{c}\text { studies } \\
\text { on } \\
\text { theories }\end{array}$} & $\begin{array}{l}\text { Sohn } \\
\text { Sei-Kwan } \\
\quad \text { et al. }\end{array}$ & $\begin{array}{l}\text { theories and methods of } \\
\text { typomorphology research } \\
\text { groups }\end{array}$ & $\begin{array}{l}\text { research methods and } \\
\text { theories of Conzenean and } \\
\text { Muratorian schools }\end{array}$ & $\begin{array}{l}\text { literature review(comparison of } \\
\text { theories, conceptions, urban form } \\
\text { elements between Conzenean and } \\
\text { Muratorian schools) }\end{array}$ & $\begin{array}{l}\text { analysis and comparison between british } \\
\text { and italian typomorphology, examination } \\
\text { of possibility for adaptation of } \\
\text { typomorphology in Korean cities }\end{array}$ \\
\hline & $\begin{array}{l}\text { Yang Seung- } \\
\text { Woo }\end{array}$ & $\begin{array}{l}\text { concepts, viewpoints and } \\
\text { methods of urban } \\
\text { morphology scholars }\end{array}$ & $\begin{array}{l}\text { German urban morphology } \\
\text { theories }\end{array}$ & $\begin{array}{l}\text { literature review(comparison of } \\
\text { viewpoints, objects and methods) }\end{array}$ & $\begin{array}{l}\text { analysis and resume of German urban } \\
\text { morphology characters by classification of } \\
\text { emerging and establishment periods }\end{array}$ \\
\hline & Tufayel et al. & $\begin{array}{l}\text { travel time and distance, } \\
\text { urban structure, citizen } \\
\text { behavior (Vancouver, } \\
\text { Halifax) }\end{array}$ & $\begin{array}{l}\text { travel time and distance of } \\
\text { workers between home } \\
\text { and office }\end{array}$ & $\begin{array}{l}\text { analysis of time and distance data for } \\
\text { analysing correlation between } \\
\text { behavior and urban form }\end{array}$ & $\begin{array}{l}\text { analysis of efficiency through examination } \\
\text { of correlation of traveling time and } \\
\text { distance between home and office }\end{array}$ \\
\hline \multirow{4}{*}{$\begin{array}{c}\text { studies } \\
\text { on urban } \\
\text { forms } \\
\text { analysis }\end{array}$} & $\begin{array}{l}\text { Jin Young-ho } \\
\quad(2003)\end{array}$ & $\begin{array}{l}\text { district unit plan, annual } \\
\text { average completion rate, } \\
\text { streets, lots, building use } \\
\text { (Donheamunro) }\end{array}$ & $\begin{array}{l}\text { GIS data, time series map } \\
\text { in } 1912 \text {, district unit plan }\end{array}$ & $\begin{array}{l}\text { transformation of zoning, frequency } \\
\text { factor of change of streets, lots, } \\
\text { building completion rate }\end{array}$ & $\begin{array}{l}\text { For urban historical center, preserving } \\
\text { characters of urban forms is more } \\
\text { important than development on large scale. }\end{array}$ \\
\hline & $\begin{array}{l}\text { Cho, } \\
\text { Joon-Beom } \\
\text { et al. } \\
(2007)\end{array}$ & $\begin{array}{l}\text { urban fabric, parcels } \\
\text { (Bukchon) }\end{array}$ & $\begin{array}{l}\text { aerial photograph, cadastral } \\
\text { map, land register map }\end{array}$ & $\begin{array}{l}\text { type division for urban fabric } \\
\text { presenting identical characters, } \\
\text { division and combining lots, anayse } \\
\text { of urban form transformation of } \\
\text { Bunchon }\end{array}$ & $\begin{array}{l}\text { Characters of historical urban forms are } \\
\text { appeared in urban fabric of small scale } \\
\text { inside of blocks and transformation of } \\
\text { parcels forms derived from change of } \\
\text { building type. }\end{array}$ \\
\hline & \begin{tabular}{|} 
Jin Young-ho \\
et al. \\
(2009)
\end{tabular} & $\begin{array}{l}\text { streets, lots, buildings and } \\
\text { building uses } \\
\text { (Bukchon, Donhwamunro) }\end{array}$ & $\begin{array}{l}\text { GIS map, time series } \\
\text { cadastral maps, land use } \\
\text { plan }\end{array}$ & $\begin{array}{l}\text { measurement of transformation } \\
\text { degree by GIS data: street(width, } \\
\text { extension, creation), lots(combine, } \\
\text { division, creation), building(change } \\
\text { of facade, expansion, reconstruction, } \\
\text { stories and structure) }\end{array}$ & $\begin{array}{l}\text { Traditional urban morphology presents } \\
\text { characters of irregular forms and small } \\
\text { scale. Transformation of streets and } \\
\text { combining lots need to be approached } \\
\text { carefully, because they bring disparate } \\
\text { changes in urban forms. }\end{array}$ \\
\hline & $\begin{array}{l}\text { Kim Min-ha } \\
\text { et al. } \\
\text { (2013) }\end{array}$ & $\begin{array}{l}\text { castle, urban forms, street } \\
\text { network, blocks, plots } \\
\text { (Pyeongyang) }\end{array}$ & $\begin{array}{l}\text { Pyeongyang castle map, } \\
\text { maps in } 19 \text { th century, tour } \\
\text { guide map, photos }\end{array}$ & $\begin{array}{l}\text { comparison of locations between } \\
\text { Pyeongyang castle map and cadastral } \\
\text { map }\end{array}$ & $\begin{array}{l}\text { Transformation of urban forms in } \\
\text { Pyeongyang in late Josun period is } \\
\text { characterized by demolition of } \\
\text { Pyeongyang castle, urban expansion, } \\
\text { changes of blocks, lots and buildings. }\end{array}$ \\
\hline
\end{tabular}


Muratori School in order to propose the possibility of applying typo-morphology to identify historicity of Korean residence and cities. He claimed that it is possible to apply typo-morphology as a method to research how Korean cities and residential types have been developed. He understood the structures as one of the units composing the urban tissue and claimed that it is required to understand architectural typology linked with urban morphology. Also, Yang, Seungwoo(2000, 2002) supplemented the preceding researches by studying the development process of German urban morphology while other researches had been focusing on British urban morphology. He classified the development period of German morphology into beginning period and organization period and compared analysis factors and research methods of major scholars.

Other foreign researches focus on urban forms within urban geography. Recently, Tufayel A. Chowdhury(2013) conducted urban form change analysis based on movement time and distance to study the correlation between urban form and community formation efficiency2), and Rémy Alain(2004) analyzed urban form components and characteristics of modern urban forms from the perspective of urban geography. Especially, various scales of urban form and structure analysis was conducted including the regional level and internal urban structure to apply urban form analysis to modern city planning. ${ }^{3)}$

One of the researches studying the forms of individual city is the research conducted by Jin, Yeonghyo(2009) which categorized the changing level of form factors composing the center of Seoul and identified the characteristics of each category. He proved that disparate changes of urban tissue are impacted more by lot volume than streets and that disparate urban forms are appeared after redevelopment, etc. He also studied the impact of urban planning regulation on urban form changes focusing on Donhwamunno and its adjacent areas. (2007) He analyzed the status of use district and district unit regulations to identify the impact on urban form components. Cho, Junbeom(2003) studied the correlation between urban architectural regulatory system and urban

\footnotetext{
2) Tufayel A. Chowdhury, Darren M. Scott, and Pavlos S. Kanaroglou, Urban Form and Commuting Efficiency: A Comparative Analysis across Time and Space, Urban Studies, 2013.

3) Rémy Allain, La morphologie urbaine, Armand Colin,, 2004
}

tissues as well as the urban issue changes in Bukchon occurred by lot-subdivision.

While most of the researches focus on Seoul downtown area, Kim, Minha, etc(2013) studied the urban form changes by comparing the images of Pyeongyang and original cadastral map of Pyeongyang area in 1914. Also, as a research on foreign urban forms, Han, Gwangya (2013) conducted the research on urban forms changes of Cordoba in Spain by linking with Islam culture. In addition, Cho, Junbeom(2013) researched the characteristics of grid-type urban forms in Denver, United States, which indicates that there are many ongoing researches on urban forms and they are expanding the research range and scope.

That is, the preceding researches focusing on Korean cities studied the time sequential changes of components such as lot volume, structures, floor space index, road forms, etc and covered partial areas of certain urban center. On the other hand, this study is differentiated from preceding researches by identifying the characteristics and difference between urban tissues developed in different eras within a city.

\section{Trace of Historical Cities and Characteristics by Each Era}

\subsection{Historical urban center areas}

Historical urban center areas of Seoul has been developed since Joseon dynasty and include the royal palace, Jongmyo, Jongno and Cheonggyecheon. Jongno demonstrates the characteristics of a planning urban structure which connects Dongdaemun and Seodaemun composing the East-west axis of the urban structure and the palace and Jongmyo are connected around them. On the other hand, residential areas and other urban areas demonstrate the characteristics of naturally developed urban structure where streets, lots and buildings are formed around the waterway of Cheonggyecheon. Based on this natural urban structure and forms, the historical urban forms of Seoul have been changed by the modern city planning during early $20^{\text {th }}$ century and road expansion and land readjustment during late $20^{\text {th }}$ century.

The street network of Seoul's historical urban center demonstrates both winding streets formed naturally by the 


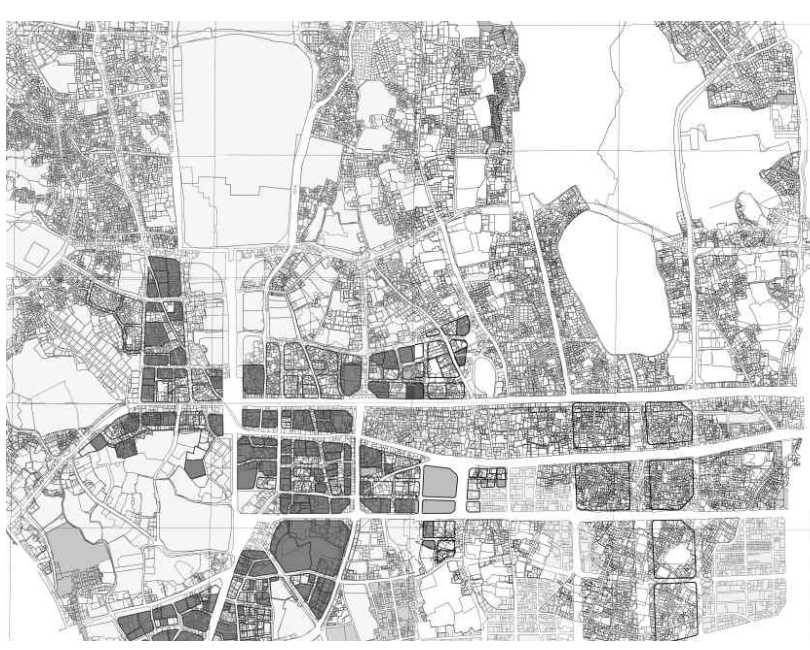

Fig 2. Transformation of historical center of Seoul by land readjustment (1919 2000) (source: Research for restoration of Cheonggyechon, 2003, Seoul Institute)

\begin{tabular}{c|c|c|c|}
\hline Dynasty Josun & $1920 \sim 1930$ & present \\
\hline & & \\
\hline
\end{tabular}

Fig 3. Transformation of street network (source: History of seoul transportation 2000 year, 2000, Seoul Institute)

landscape and waterway and wide and straight streets formed by urban planning during $20^{\text {th }}$ century. The T-type structure composed of East-west axis Jongno and South-north axis Namdaemun is changed to the street network reinforcing the South-north axis by the street connecting Gwanghwamun and Seoul City Hall and also by the formation of tram route. Especially, the South-north axis in front of Gwanghwamun is winded to connect Kyungsung Municipal Government Building(Current Seoul City Hall) and Namdaemun and also extended to connect Japanese military base in Yongsan, which occurred the changes in urban forms including curved axis and square. In addition, a square appeared in front of Namdaemun and City Hall after removal of Hanyang castle and the radial-type street network was planning around the square. Therefore, the Baroque-type urban forms have been adopted in Seoul, which is characterized by radial urban structure crossly connecting major urban infrastructures and the square.
The traditional block shapes in this area were atypical and irregular and were changed to rectangular structures after road establishment and expansion in early $20^{\text {th }}$ century, designation as urban redevelopment district in 1970s, and various development projects during 19801990.(Fig4-A) In terms of streets and lots, there are three types of urban forms including traditional urban form areas around Jongno(Fig4-B), readjustment district with relatively uniformed block shapes and size(Fig-4B), and district with large-scale road and high-rise buildings while there are still small-scale lots remain inside the block. (Fig4-D)

Areas around Jongno and Donhwamungil where urban forms during Joseon dynasty remain, there are oblique streets naturally formed around the waterway, irregular streets, small-scale lots, and ᄃ-shaped buildings. Also, there is Pimatgil in the back of Jongno and Donhwamunro which is connected by internal street network of adjacent block and forms the thin layer in the back of modern streets. The vertically narrow, long and small-scale lots adjacent to the main street compose the morphological characteristics of historical urban centers. (Fig4-B)

The shapes of blocks around north side of Jongno and Donhwamunro demonstrate square and rectangular figures formed by modern streets developed after 1900s. However, the streets inside of the block and lotsubdivision shapes demonstrate natural development characteristics, which are irregular and small-scale. Lots and buildings adjacent to external streets are standardized while street network inside of the block is irregular including dead end and disconnected streets. (Fig4-B)

On the other hand, the street network inside of the block in areas around Gwanpyeongdong south of Jongno, where land adjustment and downtown redevelopment had been conducted, demonstrates grid-type and rectangular shape with long East-west axis. The size of block is approximately $70 \mathrm{~m} * 50 \mathrm{~m}$ and is small which is $100 \mathrm{~m}$ in the longer side and $30 \mathrm{~m}$ in the shorter side. (Fig4-C) Also, the blocks around Euljiro where combination of lots had been conducted after redevelopment demonstrate winded internal street network rather than standardized and grid-type street network and the lot system is also irregular and atypical. The width of internal streets is also diverse 


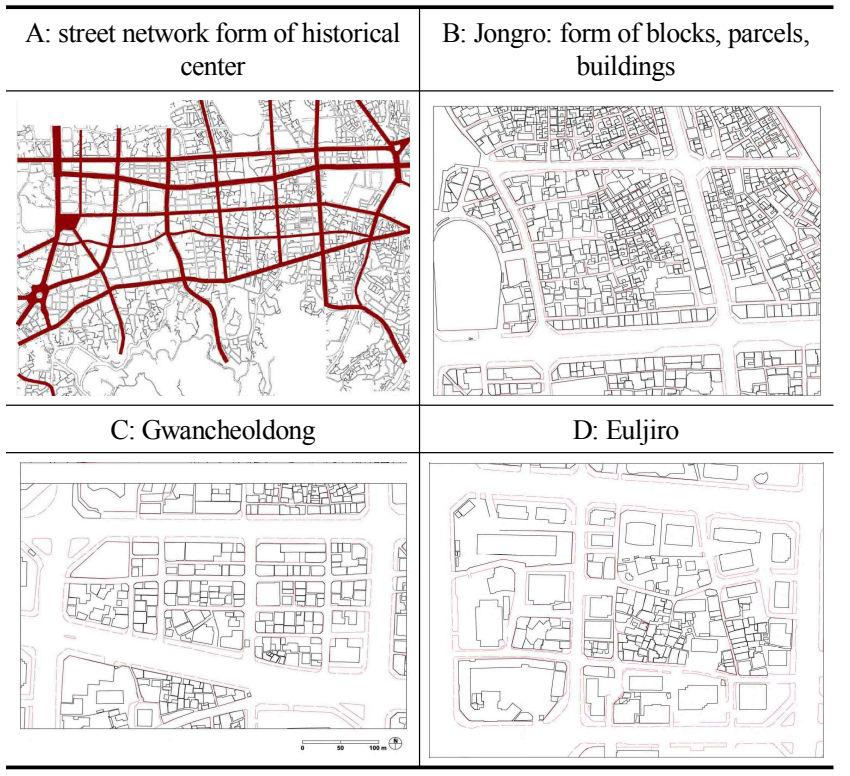

Fig 4. Urban form of historical center of Seoul(Choi Min-Ah, Linéarité des villes nouvelles de Séoul 2007)

and there are even streets with less than $4 \mathrm{~m}$-width, which is the institutional minimum road width. (Fig4-D)

Likewise, in areas where traditional street network and modern street network coexist, the lot system and buildings are also various. The lots adjacent to right angle crossing external road demonstrate modern urban planning characteristics while there are remaining narrow paths, lot-subdivision and lots disconnected to the street network. Large-scale lots adjacent to the urban principal road and small-scale and irregular lots and buildings inside of the block indicate the complexity of the era in the area.

\subsection{Urban centers in modern period ${ }^{4)}$}

The urban structure formed by topography and geographical characteristics was greatly changed by development of train and trolley during early $20^{\text {th }}$ century and removal of castles. Train was first introduced in Korea since opening of Gyeongin Railroad Line in 1899 and railway stations were built outside of the castle such as Seoul Station, Cheongnyangni, Yongsan and Yeongdeungpo. Urban districts were expanded following the railroad

4) Urban forms during 'Modern period' is developed by city planning during Japanese occupation period and there are arguments on the propriety of including the city planning at this period as Korean urban form analysis. In this research, developed areas during early 20th century are considered as 'Historical' urban form rather than 'Traditional' urban form. The 'Tradition' in this research indicates preservation of 'Value' and 'History' is 'Fact in the past' excluding the judgment of value.

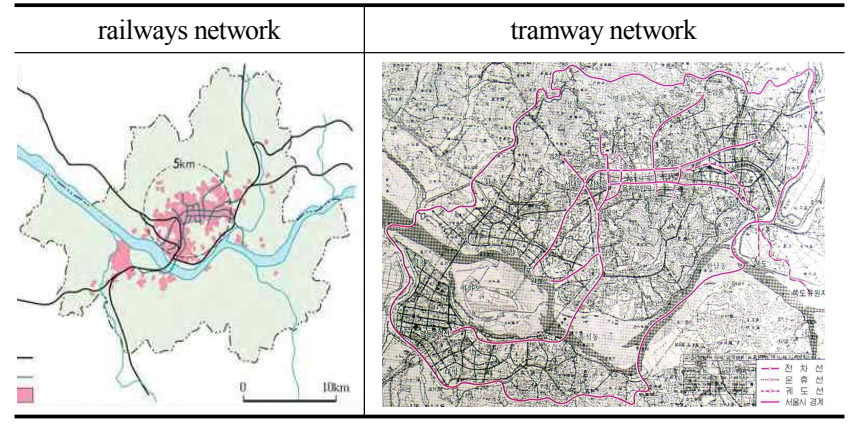

Fig 5. Railway network and urban extension of Seoul in early 20th century(source: History of seoul transportation 2000 year, 2000, Seoul Institute)

network and areas around railway stations were developed as the center of transportation.5)(Fig 5) The characteristics of urban area during the period when modern city planning began to be applied to traditional urban structure, can be summarized as formation of streets expanding the urban districts, expansion of urban districts following the street network and introduction of infrastructures. Also, the areas developed as the major transportation point during this period are still the subcenter of Seoul until now.

Yongsan, Cheongnyangni and Yeongdeungpo are areas where railway stations are located and there are plazas in front of the stations and areas around the plazas are mainly developed while small-scale lots in the past still remain. The shape of street network is grid-type and trapezoid which is relatively standardized and indicates the characteristics of modern urban planning. (Fig6-A) Yongsan area is greatly influenced by the geographical factors and is atypical, long and narrow due to obstacles in formation of road network such as railroad and river. In other railway stations, there is a plaza with the station as the center as well as the radial-shaped street network. However, in Yongsan, radial-shaped street network is difficult to be formed due to geographical factors and lots in front of the station could not be developed because of Japanese military base in the past. (Fig6-C)

The characteristics of modern urban districts are demonstrated in Yeongdeungpo and Cheongnyangni, which is represented by rotary and circular plaza formed

5) As demonstrated in Fig 5, the urban district during early 20th century was expanded following the railroad network and areas around Cheongnyangni, Yongsan, Yeongdeungpo were developed. Therefore, Cheongnyangni, Yongsan, Yeongdeungpo were designated as modern urban districts in this research to be analyzed. 
around the stations. In the street network map around Cheongnyangni area shows that circular-shaped plaza is formed by grid-type street network in Shinseoldong area converged around the node. The urban issue with combination of grid-type and radial-type forms is a mixture of Baroque urban planning in $19^{\text {th }}$ century and modern urban planning, which indicates that modern urban form is the morphological characteristics of urban districts developed during this period. (Fig6-A)

One of the morphological characteristics of blocks and lots is rectangular shape following the major horizontal axis. In European cities, the lots are narrow and deep while the lots and blocks in Korean cities are long alongside of the horizontal axis. This is one of the characteristics of readjusted blocks and lots which also impacts the shape of buildings. The size of blocks is similar to that of historical centers which is approximately $80 \mathrm{~m} * 40 \mathrm{~m}$. Sometimes, blocks are divided by the small-scale streets within the blocks but most of the times, the streets within the blocks are not well developed. In some cases, blocks are divided by the streets with length under $4 \mathrm{~m}$, which forms four columns with two lots adjacent to one another.

The other characteristic of traditional urban form demonstrated in Cheongnyangni, Yongsan, Yeongdeungpo is the trace of traditional city remained in the side of newly constructed road in accordance with urban planning. Inside of the block, there is a thin layer between the station and constructed road and it is an urban morphological characteristic commonly demonstrated in Cheongnyangni, Yongsan, Yeongdeungpo. (Fig6-B,D,E,F) Also, the street network is concentrated around the plaza in front of the station. Yongsan is T-shape (Fig6-D) while the road is diagonally converged to the station in Cheongnyangni and Yongsan. (Fig6-B,D)

The urban districts developed during this period have the characteristic that small-scale lots formed in the past still remain until now. In urban center areas, both modern urban forms and traditional urban forms coexist through combination of lots, etc while in this area, the street network is organized after land readjustment but natural geographical features and naturally occurred streets are remained in the inside. The lines dividing the blocks converge at oblique angle and there are traces of traditional

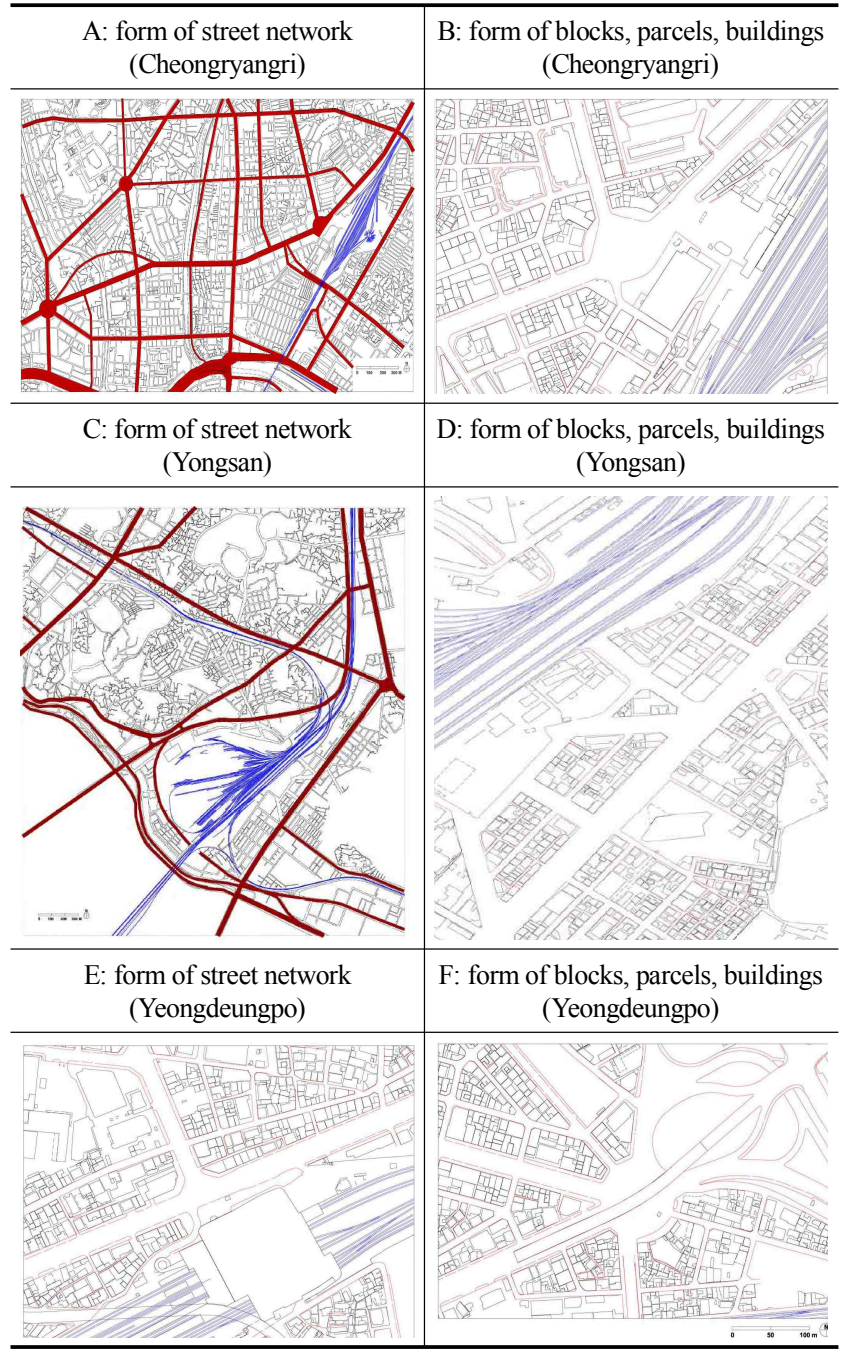

Fig 6. Urban form of Seoul urban centers developed in the modern period(Choi Min-Ah, Ibid)

lots inside of the block such as dead end streets and irregular road. (Fig6-B,D)

\subsection{Trace of historicity within modern urban forms and limitations}

The urban forms of traditional urban centers and areas developed during modern period are greatly influenced by geography and natural factors while Gangnam area is formed by urban planning after late 1960s and is hardly influenced by geography. As demonstrated in the topographic map in 1974 , the area is planned to be formed as grid-type street network and current urban structure is formed after road construction and lot-subdivision in accordance with the land adjustment projects. (Fig7-A)

The street network of Gangnam area is similar to square shape unlike the previously developed street network 
which has East-west direction. The grid-type street network was planned at large-scale and accordingly, the blocks are much larger than those in the past. The size of general blocks in this area is $150 * 70 \mathrm{~m}$ and the larger ones are $150 * 100 \mathrm{~m}$, which is about two times larger than blocks formed during modern period. (Fig7-B)

The shape of blocks is standardized which is divided by grid-type street network but the size of blocks is irregular. The shape of road and lots is different between the side adjacent to the principal road and inside of the blocks. The street network inside of the blocks is not a complete grid-type. The division made by streets inside of the blocks indicates that sometimes, straight streets with length of $4 \sim 8 \mathrm{~m}$ pass through the blocks at East-west or South-north direction but there are also streets that are disconnected from the principal road because street network inside of the blocks is redivided into smaller streets. In this case, streets passing through the blocks perform the distributing role for smaller streets. (Fig7-B)

Observation of lots within the blocks demonstrates that lots adjacent to the principal road are large-scale and rectangular to be used as the location of commercial and office buildings. On the other hand, the lot system within the blocks is rectangular with the direction opposite to lots adjacent to the principal road. This is formed by lots adjacent to inside of backside road dividing the lots adjacent to principal road into two parts. The lots inside of the backside road is small-scale and often used as neighboring convenience facilities and residential buildings. The lots often have double columns. (Fig7-C,D)

The differences between Gangnam area and historical urban centers and urban forms developed during modern period are shape of street network, size of blocks $\cdot$ lots and lack of connectivity in street network inside of the blocks. One of the characteristics of the urban tissues developed before modern period such as Jongno, Yeongdeungpo, Yongsan, etc was the street network at the back of the principal road being connected to street network inside of the adjacent blocks. This characteristic is formed when principal road is expanded in the naturally developed urban tissues and it well demonstrates the connectivity of previous urban spaces. Also, the small-scale narrow and deep band developed in the backside of principal road is a

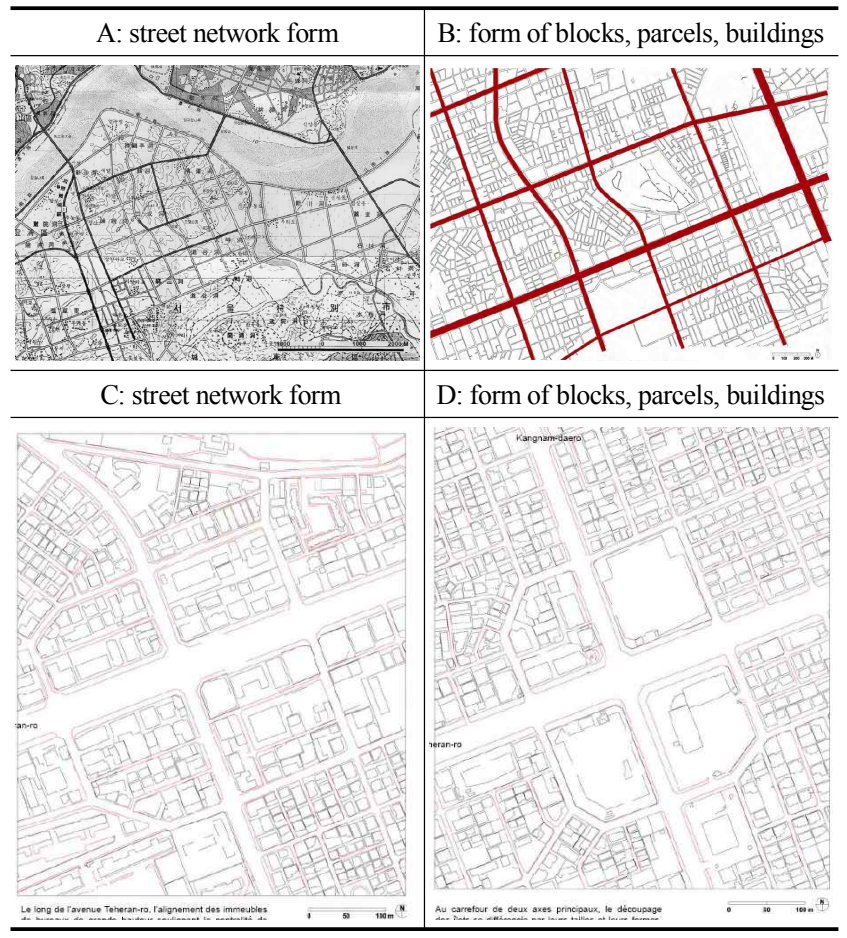

Fig 7. Urban form of comtemporary urban center(Choi Min-Ah, Ibid)

common characteristic shown in both historical and modern urban centers, which composes the morphological feature of Korean cities that had been developed focusing on walking.

On the other hand, Gangnam area developed during modern times does not show clear indication of connectivity in backside road. Especially, there are large-scale lots for large-scale office buildings planned at the node of arteria streets which disconnects the flow of backside road between the blocks. Unlike the principal road developed for vehicles, backside road is developed for pedestrians and it demonstrates for characteristics of Korean urban streets. In the areas developed before and during modern times, the connectivity between blocks is insufficient due to the streets inside of the blocks and lot-subdivision.

3.4. Comparison of morphological characteristics of urban centers by each period

As a result of analyzing the shapes of urban centers developed during three different period, there were common characteristics as well as different characteristics. There were a lot of common characteristics between historical and modern urban centers in terms of street 
network, blocks, and lot system while the structure of urban center developed during modern times was greatly differentiated from those developed in other period.

In terms of street network, the size became bigger as time passed by and it became grid-shaped. However, size of the grid was radically changed which was similar in historical urban center and modern urban center while it is almost doubled in contemporary urban centers. Also, the historical and modern urban centers had been developed at East-west direction to connect the two gates(Daemun) formed during $14^{\text {th }}$ century. In the contemporary urban centers, it is difficult to find East-west axis which is morphologically differentiated with other period. In terms of forms, the historical urban center was developed based on traditional city structure and its shape was determined by expanded and newly constructed principal road thus its shape is long at East and West direction. Modern urban center is also long at East and West direction and demonstrates standardized grid-type shapes. However, in the urban center developed during these two time period, there are small-scale streets developed within the blocks so there is partial irregularity with remaining naturally occurred street network. Therefore, the connectivity between the streets is insufficient in many places.

However, in spite of these similarities, the modern urban center has its unique morphological characteristics differentiated from the historical urban center such as the plazas and radial-shaped street network developed around the stations. Meanwhile, in contemporary urban center such as Gangnam area, the street network is grid-shaped and the size is also standardized.

The common characteristic of street network developed in historical, modern and contemporary urban center is the development of backside road. However, unlike in historical and modern urban center with thin and narrow path formed at the back of the principal road, the backside road in contemporary urban center becomes thick due to large-scale lot planning adjacent to the principal road. Especially, in terms of the connection between the backside road and its adjacent block, the backside road and its adjacent blocks is disconnected in comtemporary urban center because of square and large-scale lot located at the corner of the block while the connection is maintained in
Table 2. Comparison of urban centers forms by developed periods

\begin{tabular}{|c|c|c|c|}
\hline & street network & blocks & parcels \\
\hline $\begin{array}{c}\text { historical } \\
\text { urban } \\
\text { center }\end{array}$ & $\begin{array}{l}\text { east-west axis, } \\
\text { rectangular forms } \\
\text { for arterial roads, } \\
\text { irregular and } \\
\text { organic forms for } \\
\text { inner secondary } \\
\text { roads }\end{array}$ & $\begin{array}{l}\text { about } 70 \mathrm{~m} * 50 \mathrm{~m} \sim \\
30 \mathrm{~m} * 50 \mathrm{~m}, \\
\text { linear form, } \\
\text { mixed forms } \\
\text { between regular and } \\
\text { origin forme }\end{array}$ & $\begin{array}{l}\text { small and divers } \\
\text { dimension, } \\
\text { spontaneous formed } \\
\text { morphology, } \\
\text { irregular } \\
\text { arrangement }\end{array}$ \\
\hline $\begin{array}{c}\text { modern } \\
\text { urban } \\
\text { center }\end{array}$ & $\begin{array}{l}\text { east-west axis, } \\
\text { rectangular forms } \\
\text { for arterial network, } \\
\text { radialzed structure } \\
\text { spread out street } \\
\text { network from plazas } \\
\text { as baroque style city }\end{array}$ & $\begin{array}{l}\text { about } 80 * 40 \mathrm{~m} \text {, } \\
\text { mixed forms } \\
\text { between regular and } \\
\text { origin forms, } \\
\text { rarely pentagon or } \\
\text { triangle forms }\end{array}$ & $\begin{array}{l}\text { small dimension, } \\
\text { mixed between } \\
\text { regular and } \\
\text { spontaneous forms, } \\
\text { rectangular forms } \\
\text { for planned parcels }\end{array}$ \\
\hline $\begin{array}{c}\text { contem- } \\
\text { porary } \\
\text { urban } \\
\text { center }\end{array}$ & $\begin{array}{l}\text { grid pattern, } \\
\text { non east-west axis, } \\
\text { regular forms and } \\
\text { large size } \\
\text { non influence of } \\
\text { topographic } \\
\text { characters }\end{array}$ & $\begin{array}{l}150 * 70 \mathrm{~m} \sim 150 * 100 \mathrm{~m} \text {, } \\
\text { regular and } \\
\text { rectangular forms, } \\
\text { large scale on cross } \\
\text { roads }\end{array}$ & $\begin{array}{l}\text { large dimension, } \\
\text { especially for } \\
\text { parcels nearby } \\
\text { arterial roads and } \\
\text { parcel on corners, } \\
\text { regular scale and } \\
\text { rectangular forms }\end{array}$ \\
\hline
\end{tabular}

previous urban centers. These kinds of morphological characteristics bring the lack of linkage between the blocks and disconnection in the flow in the contemporary urban center.

In terms of shape and size of blocks, modern urban center is larger than historical urban center, while contemporary urban center is larger than modern urban center. However, the difference in size is small between historical and modern urban center while the block size in contemporary urban center is almost doubled compared to before. It is also linked with difference in lot size. In historical urban centers, the lots are irregular and there are small-scale lots with different sizes while its arrangement is also inconsistent. On the other hand, planned combination and naturally occurred lot-subdivision coexist in modern urban center. In contemporary urban center, the shape and combination method are consistent and regular. The lot system in historical and modern urban center are similar to square shape which indicates one of the characteristics of lots in Korean cities unlike western countries with narrow and deep lots.

4. Institutional Issues and Measures for Preservation of Historical Urban Forms

\subsection{Status and issues of district unit plans}

The changes and formation of Korean cities could be 
classified into built-up urban districts and newly conducted building and land development projects. The institutional factors impacting the urban forms in built-up areas are maintenance plans and district unit plans while newly constructed districts are impacted by land development projects or new town projects. In case of built-up areas, its forms change followed by removal and development of buildings in each lot, but the lot system and streets are changed by development projects and district unit plans.

The purpose of district unit plans is to supplement city plans based on use zoning. It enables to establish detailed plans taking regional conditions into consideration as well as proposing detailed planning criteria with the purpose of improving city function, appearance and land utilization. This is an integration of city planning regulations introduced in 1983 for city beautification, urban design district of urban planning law introduced in 1991 and urban design institution in 1994. It was first introduced in 2000 and is an important factor in urban planning regulating the two and three dimensional urban form components such as streets, blocks, lots, building lines, building height, roof-lines, colors, etc.

In Seoul, district unit plans are established for major areas including urban center, subcenter, center of region • district and station influence area for maintenance of the city. District unit plans does not force the change of urban forms but aims to change the urban space gradually by proposing the frame and direction when buildings are newly constructed or reconstructed.

However, the analysis of district unit plans recently established by Seoul local government demonstrates that there are certain patterns in the direction of urban forms. In areas where principal roads are crossed, combination of lots is planned and floor area ratio is increased to induce high-density development. Also, combination of smallscale lots around principal roads is also induced and pedestrian passage is located between the large-scale lots to enable smooth flow of pedestrians between the blocks.

However, these planning direction is different from the previous urban forms and structures in Korea so it could eliminate the connectivity between similar-scale lots and the flow of small streets in the backside road. Construction of large-scale buildings followed by combination of lots

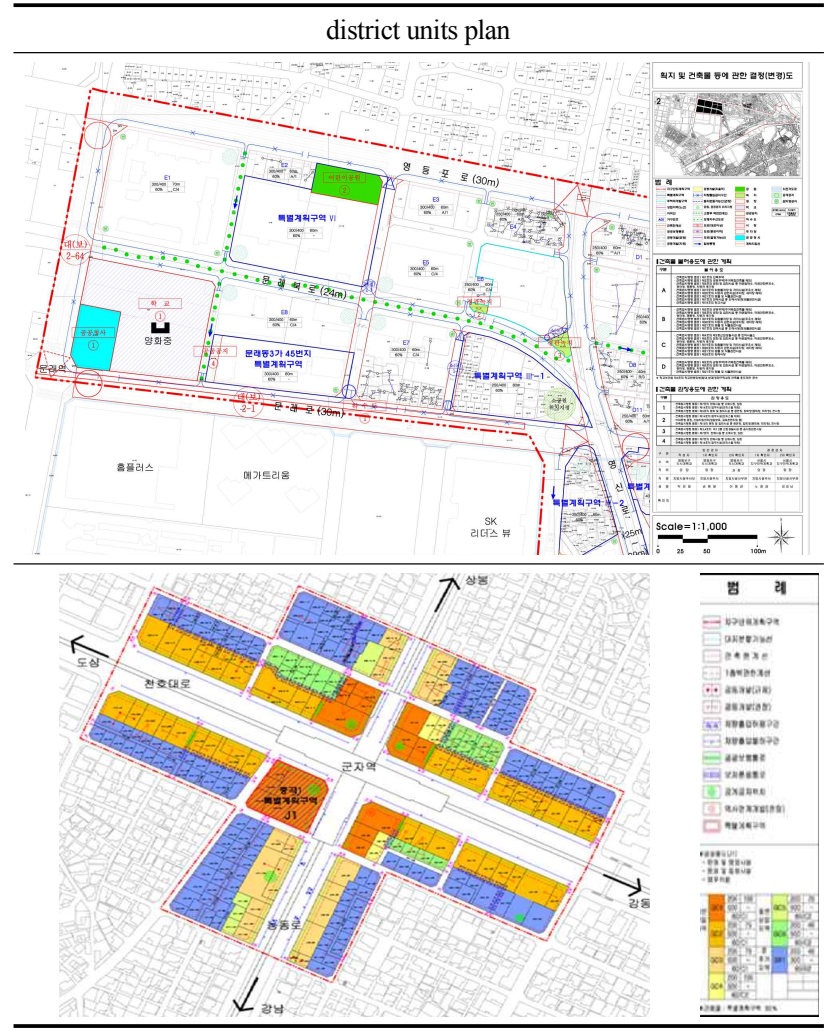

Fig 7. Yeungdeungpo, Gunja district units plan (source: Yeungdeungpo urban center district units plan, Gunja district units plan)

around principal roads is contrary to traditional urban structures of Korea which has small-scale lots and similar-scale buildings. Therefore, it could damage the historicity and temporal connectivity of the city. These characteristics in district unit plans are also demonstrated in Yeongdeungpo, the subcenter of Seoul as well as in Gunja station formed by land readjustment. $\left.{ }^{6}\right)$

District unit plans, which are institutional measures for modern urban planning aim to increase land utilization efficiency and activation of pedestrian moving flow but combination of lots to construct large-scale buildings could be the obstacles in urban restoration under recent limitation of development needs and stagnation of real estate. Therefore, the standardized large-scale lot combination plan, increase in floor area ratio, construction of pedestrian path around principal roads should be reconsidered. These institutions are far from historical

6) First-type district unit plan for Yeongdeungpo area, district unit plan modification, topographical map, district unit plan map for Gunja station area in Gwangjingu, Yeongdeungpo area is a modern urban center and is an area selected to be analyzed in chapter 3 . This area is selected to compare contemporary urban planning established in modern urban center. 
forms of Korea and if the directions are maintained, historical characteristics of Korean cities could be eliminated and it could bring uniformed city form without any uniqueness.

\subsection{Issues and measures regarding new town construction}

New town construction in Korea is conducted mainly by land development projects, new town construction project, etc. Land development plans are established by referring to the land development guidelines and new town project plans are established based on Sustainable New Town Planning Criteria and land development guideline.

As a result of reviewing related planning criteria, the land development projects propose detailed urban forms regarding block-type detached housing site among the types of housing site. The block-type detached housing site has the characteristic that provides construction site for detached houses, Korean-style houses and apartment houses under three-story by blocks.7) The types of floor plans for block-type detached housing site designated in the guideline are surrounding type, Cul-De-Sac type, linear type and dispersion type and their concepts and deformation forms are suggested with examples. (Land development guideline attachment 5) However, the surrounding type and Cul-De-Sac type are mainly

Table 3. Evaluation indicators for urban durability (source: Guideline for Evaluation of urban durability and infrastructures appendix)

\begin{tabular}{|c|c|c|}
\hline sector & indicators & subject of appraisal \\
\hline \multirow{4}{*}{$\begin{array}{l}\text { land } \\
\text { use }\end{array}$} & $\begin{array}{l}\text { ratio of concentration of } \\
\text { development area }\end{array}$ & $\begin{array}{l}\text { ratio of developed area in comparison } \\
\text { with development permitted area }\end{array}$ \\
\hline & ration of economical land use & $\begin{array}{l}\text { non used land area in comparison } \\
\text { with converted area for housing, } \\
\text { commercial and industrial use }\end{array}$ \\
\hline & $\begin{array}{l}\text { optimal land quantity based on } \\
\text { demand }\end{array}$ & $\begin{array}{l}\text { conversion of land zoning in } \\
\text { comparison with } \\
\text { planned population }\end{array}$ \\
\hline & $\begin{array}{l}\text { supply of planned land in the } \\
\text { non urbanized area }\end{array}$ & $\begin{array}{l}\text { supplied land area in comparison with } \\
\text { converted land }\end{array}$ \\
\hline \multirow{4}{*}{$\begin{array}{c}\text { culture- } \\
\text { land- } \\
\text { scape }\end{array}$} & $\begin{array}{c}\text { condition of cultural and sports } \\
\text { facilities }\end{array}$ & $\begin{array}{l}\text { area per person of cultural and sports } \\
\text { facilities }\end{array}$ \\
\hline & $\begin{array}{l}\text { condition of park and green } \\
\text { spaces }\end{array}$ & $\begin{array}{c}\text { area of park and green } \\
\text { spaces(including wet area) }\end{array}$ \\
\hline & $\begin{array}{l}\text { condition of community } \\
\text { facilities }\end{array}$ & $\begin{array}{l}\text { area of community facilities per } \\
\text { person }\end{array}$ \\
\hline & $\begin{array}{c}\text { level of street lanndscape } \\
\text { improvement }\end{array}$ & $\begin{array}{l}\text { length of modified street in } \\
\text { comparison with all streets length }\end{array}$ \\
\hline
\end{tabular}

7) Article 16 of Land Development Guideline traditional district plans of the United Kingdom and they demonstrate the same lot combination form in western countries.

Therefore, it is first required to identify the shapes and size of street network, blocks, lots by urban form analysis on traditional Korean cities in order to apply to land development guideline and district unit plans. Especially, in block-type detached housing sites where Korean-style houses can be planned collectively, new types of Korean-style houses should be suggested as well as the shape of Korean-style house community and lot combination method. Also, besides the block-type detached housing sites, application of traditional urban forms to street network, block type, and commercial site could be reviewed.

In addition, the Ministry of Land, Infrastructure and Transport enabled to evaluate sustainability of the city by section 2 of article 3 in National Land Planning and Utilization Act for sustainable and balanced development of the city. This evaluation is an instruction by Ministry of Land, Infrastructure and Transport and is regulated by 'City Sustainability and Living Infrastructure Guideline' The number of evaluation indicators is 30 under four categories which are land use, industry-economics, environment protection, culture landscape. However, there is no evaluation indicators included regarding urban historicity which indicates that city's sustainability is being evaluated by expansion of infrastructure and development area.

The historicity of the city is directly linked to cultural characteristics thus it has much greater impact on fundamental culture and landscape compared to current evaluation indicators such as expansion of cultural and sports facilities, size of park and green, residential meeting place and improvement of streetscape. In this sense, San Francisco of the United States has included historical preservation section in their city monitoring indicators such as remodeling and removal of historical buildings, new construction within preservation area, development right transfer, etc. ${ }^{8)}$ Accordingly, the current sustainable urban evaluation indicators of Korea should be modified to

8) 2009, Downtown plan monitoring report 2002-2007, San Francisco Planning Department, pp7-36 
focus more on historical preservation rather than size of related facilities.

In preceding researches, city evaluation indicators regarding historical preservation has been suggested, such as preservation of regional cultural tradition, reinforcement of historical and cultural functions, utilization of historical and cultural tradition, cultural sightseeing city, preservation and restoration of historical and cultural assets and cultural identity of urban center. 9) In order to reflect these indicators in the cultural evaluation, specific and quantitative indicators should be prepared. Like the ones that are currently being used such as building utilization, change of usage, building restoration, lot-system preservation ratio and street-shape preservation ratio, quantitative indicators makes it easier to be used as city evaluation indicators.

The urban form has the characteristics of fundamental factors preserving the original form and identity of the city thus should be considered as historical and cultural asset to be preserved. Preservation of historical and cultural asset includes concepts and methods such as preservation, protection, maintenance, change of usage, transfer, duplication, utilization, etc. ${ }^{10)}$ Therefore, if historical form of the city is to be preserved, it is not only possible to preserve existing historical factors remained in urban center but also duplication and restoration can be considered in areas where historical factors are eliminated such as new

Table 4. Evaluation indicators for historical and cultural characters of city (source: Bae, Young-Nam Shin, Nam-Soo, A Study on the Derivation of valuation factor in urban regeneration plan, 2008)

\begin{tabular}{|c|c|}
\hline classification & indicators \\
\hline \multirow{3}{*}{ cultural elements } & reinforcement of historical and cultural functions \\
\hline & making use of historical and cultural heritage \\
\hline & $\begin{array}{l}\text { preservation and restoration } \\
\text { of historical and cultural heritage }\end{array}$ \\
\hline \multirow{3}{*}{$\begin{array}{l}\text { historical } \\
\text { elements }\end{array}$} & respect of local culture and tradition \\
\hline & cultural and touristic city \\
\hline & enhancement of cultural originality \\
\hline
\end{tabular}

towns and land development areas. For this purpose,

9) Bae, Youngnam, Shin, Namsoo, 2008, A Study on the Derivation of Valuation Factor in Urban Regeneration Plan, Authors integrated urban regeneration evaluation indicators referred in preceding researches and classified them into comfort, culture, beauty, convenience, exchange, information, combination, safety, asset, policy to suggest specific evaluation indicators for each element.

10) Oh, Sekyeong, etc, Classification of Preservation Concept for Historical and Cultural Assets, Land Planing, p. 228, 2001 continuous maintenance by evaluation is required after adopting historical urban forms in new development plans.

\section{Conclusion}

In this research, historicity of Korean city were studied for sustainable development. By this research focusing on Seoul, it was identified that there are common characteristics between urban centers developed during $14^{\text {th }}$ century and the ones developed during modern period in terms of street network, block, lot, etc.

The areas of Korean cities also demonstrate different characteristics by the era that they are developed. In the traditional urban centers, in spite of the continuous modern city maintenance, natural factors such as waterway, naturally occurred streets and traditional lot system were remained to preserve historical urban forms. Also, the modern urban centers demonstrate unique characteristics such as rotary and radial-type street network while sharing common characteristics with the traditional urban centers in terms of lot volume and system, combination features, etc. On the other hand, the contemporary urban centers showed grid-type urban form and the composition of street network, volume and shape of street network and blocks were much more different compared to urban centers developed in the past.

However, in spite of these differences, development of backside road, non-narrow and deep lot system, etc are common characteristics demonstrated in historical, modern and contemporary urban centers. In this sense, it is required to apply urban form containing the historicity of previous cities in new town planning or urban redevelopment planning. Also, relevant institutions should be modified including district unit planning guideline, new town planning criteria, land development guideline, etc.

In order to preserve historical forms of Korea, application of modern and historical block volume, connectivity of street network in the back of the principal road should be maintained. Grid-type street network shown in contemporary urban centers will be continuously applied in upcoming urban plans but the shape of rotary demonstrated in modern urban centers is also should be preserved if considering its value indicating the characteristics of the era it is redeveloped. In addition, the 
general district unit plans applied in built-up areas often include lot combination and it brings disparate changes in various urban form features including building size, street network, etc, thus standardized lot combination in the side of the principal roads should be avoided. Also, the block volume and lot system of traditional and modern urban centers should be considered.

In foreign countries, regarding new town plans and urban redevelopment plans, disconnection with the traditional urban forms has been declared by applying vehicle movement and modernism urban planning until 1960 s, but since 1980s, they are now returning back to traditional urban forms and lot system after postmodernism period. This is because te traditional urban forms bring more intimate and comfortable life to the people living in the city. ${ }^{11)}$

Recently, the community of Korean-style houses is being planned to be constructed. This is a meaningful act to restore the urban historicity and it is a great opportunity to succeed historical urban forms and structures to contemporary cities. In this sense, it is required to analyze detailed urban forms of Korea and prepare and improve relevant institutions.

However, application of urban historicity could conflict with the needs of convenient life and installation of related facilities thus adjustment measures should be prepared. Considering that preservation area system of Korea brought deterioration of residential living environment and had more limitation impacts rather than preservation impacts, it is required to maintain convenience of the residents when applying the institutions preserving the historical forms of the city. When planning dense urban forms as in traditional urban centers, various measures such as providing parking lots, incentives, tax reduction, etc, should be established so that the residents could be positive towards the living environment within historical urban forms.

\section{References}

[1] Allain Rémy, La morphologie urbaine, Armand Colin; 2004, $254 \mathrm{p}$

11) Rob Crier, Bussy-Saint-George New Town Planning Guideline
[2] Panerai Philippe, Analyse urbaine, Parenthèses; 1999, $189 \mathrm{p}$.

[3] Panerai Ph. Carstex J. Depaule J-C, Formes urbaines, de l'ilot à la barre, collection Eupalino; 2004.

[4] Kim Min-A, Jung In-Ha. The Transformation of Pyongyang's Urban Morphology after the Late Joseon Period, 2013, v.29 n.1, pp. 217-226.

[5] Sohn Sei-Kwan, Han Ki-Jung, A Study on the Research Methods of Typemorphology, Journal of architecture institution of Korea, 1996, v.12 n.6, pp. 73-85.

[6] Jang Mi-Hyeun, A study on urban structure of housing area by period, Master's Degree Dissertation, Ewha Womans university, 2002.

[7] Cho Joon-Beom, The transformation of urban architectural regulatory system and urban tissue in Bukchon area, Seoul, Doctor's Degree Dissertation, University of Seoul, 2003.

[8] Cho Joon-Beom, Choi Chan-Hwan, A Study on the Transformation of Urban Tissues showed from subdivision and amalgamation of lots in Bukchon, Seoul, Journal of architecture institution of Korea, 2003, v.19 n.2, 125-133.

[9] Jin Young-Hyo, Ahn Kun-Hyuck, Types and Characteristics of Historic Urban Form Changes in City Center of Seoul, Urban design, 2009, v.10 n.1, pp. 103-121.

[10] Choi Min-Ah, Linéarité des villes nouvelles de Séoul: une nouvelle centralité face à l'extension urbaine et au développement du réseau de transport, Doctor's Degree Dissertation, Université Paris 8, 2007.

[11] Jin Young-Hyo, Ahn Kun-Hyuck, Park So-Hyun, Impacts of Urban Planning Regulations on Urban Form Changes in the Donwhamunro area, Seoul, Korea, Journal of the Korea planners association, 2007, v.42 n.1, pp.19-34.

[12] Han Gwang-Ya, Kim Min-Ji, Understanding The Transformation Of Cordoba's City Form, Urban Design, 2013, v.14 n.3, pp.99-118.

[13] Chowdhury Tufayel A, Scott Darren M, Kanaroglou Pavlos S, Urban Form and Commuting Efficiency: A Comparative Analysis across Time and Space, Urban Studies, 2013. vol.50, n.1, pp. 191-207. 